\title{
Uveal Melanoma Cell Seeding after Transretinal Tumor Biopsy?
}

\author{
Konrad R. Koch ${ }^{a}$ Ahmed M. Hishmi ${ }^{a}$ Monika Ortmann ${ }^{b}$ Ludwig M. Heindla \\ Departments of a Ophthalmology and b Pathology, University of Cologne, Cologne, Germany
}

\section{Keywords}

Uveal melanoma - Transretinal biopsy · Local recurrence ·

Tumor cell seeding $\cdot$ Histopathology

\begin{abstract}
Background/Aims: To report a case and the histopathology of uveal melanoma cell seeding following transretinal tumor biopsy for a suspected uveal lesion. Methods: Interventional case report. Results: A 66-year-old male presented with a pigmented perilimbal episcleral lesion overlying an intraocular mass at the pars plana, 3.5 years after transretinal biopsy and ruthenium plaque brachytherapy for a choroidal melanoma at the posterior pole. The patient underwent enucleation of the eye. Histopathology confirmed a recurrence of uveal melanoma with intra- and extrascleral tumor portions. Serial sections revealed the posterior border of this newfound pars plana melanoma separated from the radiation scar by a viable and tumor-free choroidal area, thus failing to establish a continuity between secondary and primary tumor. Conclusion: Transretinal tumor biopsy is of high diagnostic and prognostic value in the management of uveal lesions, but also bears the potential risk for tumor cell seeding.
\end{abstract}

(c) 2017 S. Karger AG, Basel

\section{KARGER}

() 2017 S. Karger AG, Basel

E-Mail karger@karger.com

www.karger.com/oop

\section{Introduction}

The first attempts of intraocular tumor biopsies reach far back in ophthalmic surgical history being credited to Hirschberg in 1868 [1]. During the first half of the 20th century, when large-bore needles and trephines were still used to obtain tissue specimens, these procedures were rarely performed and carried a significant risk of extraocular tumor seeding [1]. It was with the advent of microinvasive vitreoretinal surgery that intraocular biopsies became a feasible and more widely used diagnostic tool. New insights into the prognostic value of cytogenetical testing in uveal melanoma (UM) patients have led to a significant increase in the number of biopsies during the last 20 years.

Whether they are performed as vitrectomies or transvitreal or transscleral fine needle aspiration biopsies, the current biopsy techniques are considered as markedly safe $[2,3]$. However, until this day, iatrogenic tumor cell seeding might still represent the potentially severest of all imaginable complications. Therefore, we want to report an extremely rare case of suspected tumor cell seeding following a transretinal tumor biopsy. 


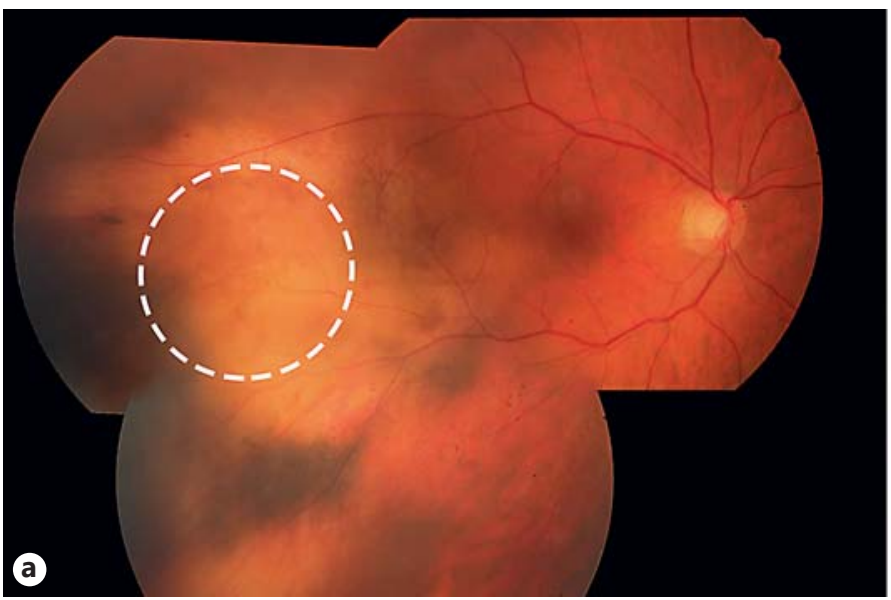

Fig. 1. A choroidal tumor was detected in the right eye of a 66-yearold male patient. a Funduscopy showed a slightly prominent, pigmented mass with moderately defined margins in the inferotemporal quadrant. Dashed circle represents the area of maximum tu-

\section{Case Report}

A 66-year-old male presented with a slightly prominent choroidal mass in the right eye localized in the inferotemporal quadrant posterior to the equator (Fig. 1a, b). Although suspicious for $\mathrm{UM}$, the atypical clinical appearance made it impossible to rule out differential diagnoses such as metastasis or lymphoma. Therefore, the patient underwent a 25-gauge 3-port pars plana vitrectomy (sclerotomies in the inferotemporal, superotemporal, and superonasal quadrants) and transretinal tumor biopsy. Histopathological evaluation confirmed UM. At the patient's request, cytogenetic analyses were performed revealing a prognostically unfavorable monosomy 3 . The patient underwent ruthenium-106 plaque brachytherapy. During the following year, the tumor height decreased resulting in an atrophic scar.

After being lost to follow-ups for 1 year, he returned with a pigmented perilimbal episcleral lesion in the 10 o'clock position of the right eye (Fig. 2a). Ultrasound biomicroscopy revealed a solid intraocular mass at the pars plana, underlying the visible extraocular portion (Fig. 2b). Based on clinical and echographic findings, this newfound intraocular tumor did not seem to be connected to the original inferotemporal UM location. At the latter, no remaining tumor was detectable. After enucleation, histopathological evaluation confirmed the suspected intra- and extrascleral UM recurrence (Fig. 2c), with Melan-A, HMB-45, and Ki-67 immunopositivity. Serial sections showed the posterior border of this newfound anterior tumor separated from the inferotemporal radiation scar by a viable and tumor-free choroidal area with some fibrotic alteration (Fig. 2d). A continuity between the secondary and the primary tumor could thus not be established.

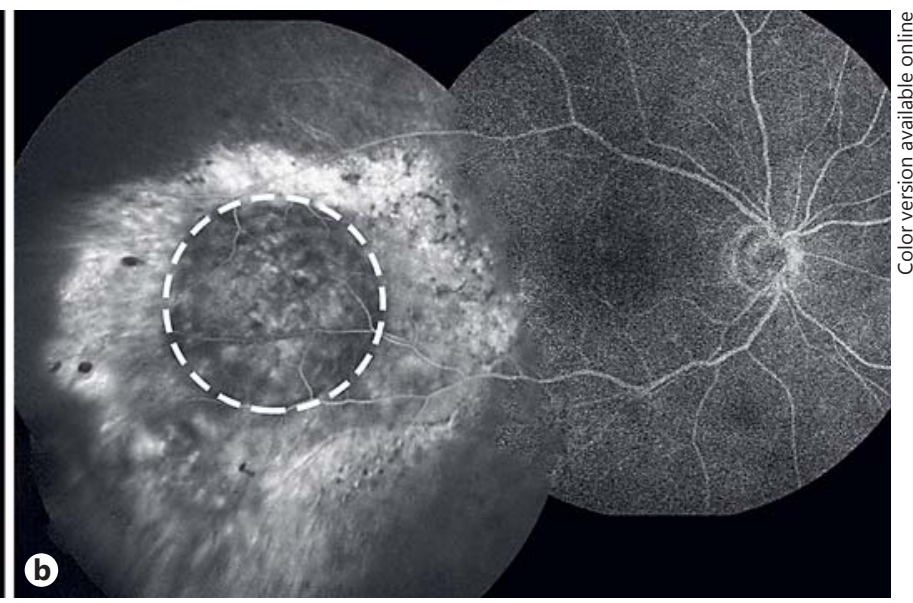

mor height as confirmed with B-scan echography. b Fluorescence angiography (late phase) revealed a circumscribed area of irregular hyperfluorescence surrounding a relatively hypofluorescent center (dashed line: area of maximum tumor height).

\section{Discussion}

With the intra- and extrascleral portions of the recurrence positioned adjacent to the superotemporal pars plana vitrectomy sclerotomy, it appears likely to us that the present case represents an example of biopsy-related tumor cell seeding. Alternatively, a continuous growth evolving from the margins of the original tumor - which might not have been sufficiently irradiated - could have arisen. However, histopathological serial sections failed to establish such continuity, making a recurrence "per continuitatem" unlikely. No active UM remnants were detectable throughout the radiation scar. Theoretically, in place of a recurrence, the anterior tumor could also represent a separate ciliary body UM with extrascleral extension. Indeed, this would be highly improbable, since the frequency of such unilateral so-called multiple UMs has been estimated at $<1: 50,000,000$ based on the minimal number of published cases [4].

The authors have explicitly no intention to question the value of transretinal tumor biopsies. On the contrary, the latter is, without a doubt, a well-established tool. It is at the same time safe and eye globe conserving [5]. It allows establishing or confirming a diagnosis in clinically inconclusive cases and provides important prognostic information [6]. In the future, with the advent of targeted or personalized cancer therapies, it might also give essential information in order to adapt the treatment to the individual tumor's genetic background $[7,8]$.

Ocul Oncol Pathol 2017;3:164-167
Tumor Cell Seeding following

Transretinal Biopsy?
DOI: $10.1159 / 000453360$ 

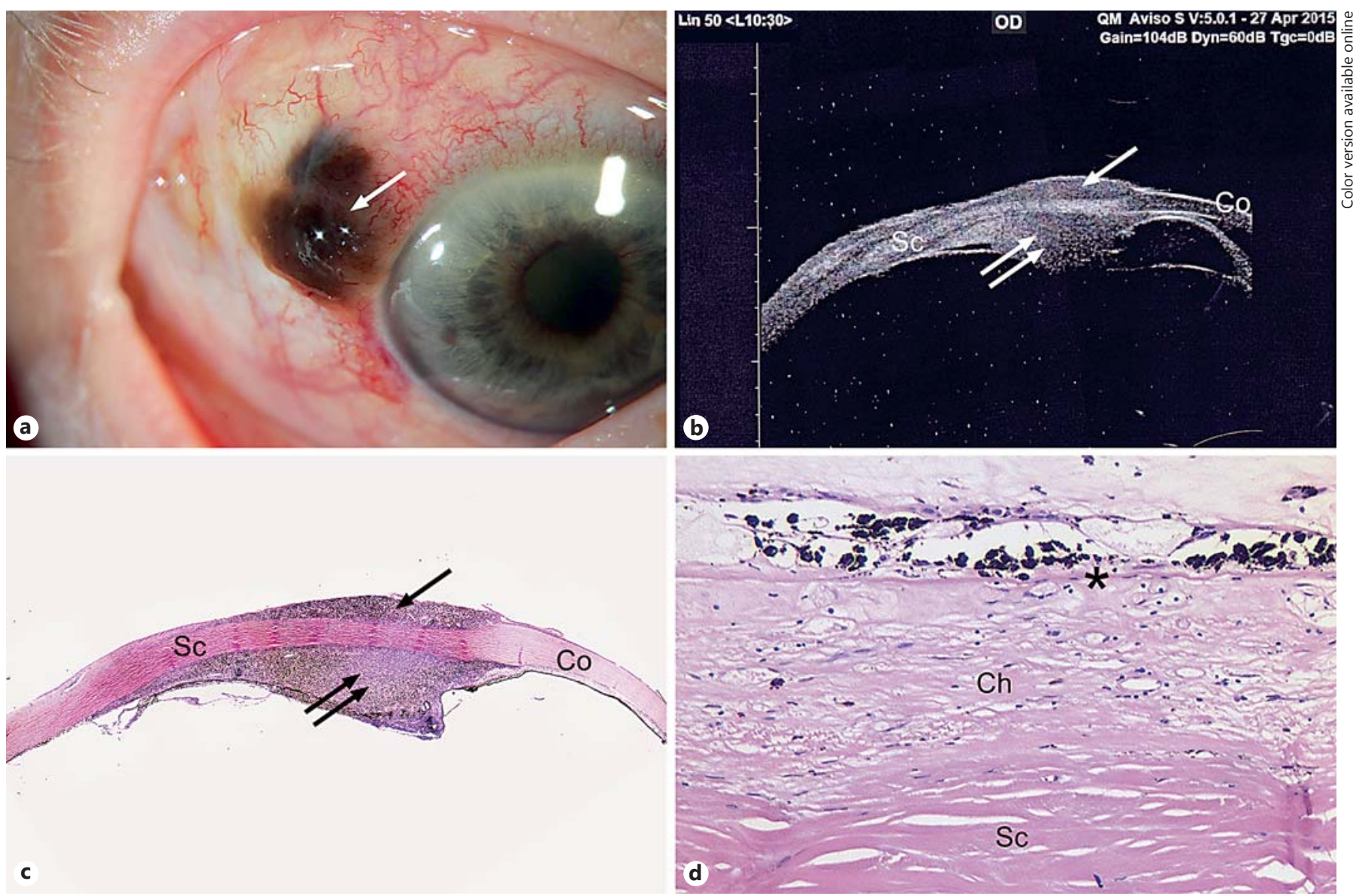

Fig. 2. The patient presented again with an episcleral mass 3.5 years after transretinal biopsy and subsequent ruthenium plaque brachytherapy of the original choroidal melanoma. a Clinically, an episcleral perilimbal pigmented mass (arrow) was seen at the 10 o'clock position. b Ultrasound biomicroscopy demonstrated an intraocular prominent tumor at the pars plana (double arrow, thickness $2.2 \mathrm{~mm}$ ) underlying the clinically visible extrascleral extension (arrow, thickness $0.9 \mathrm{~mm}$ ). c Histopathological evaluation confirmed a recurrence of the uveal melanoma, with intra- (double

The present case illustrates simultaneously the diagnostic and prognostic values of transretinal tumor biopsies as well as the potential risk for tumor cell seeding, even if this is extremely rare. In a detailed literature search, we were able to identify a total of only 6 cases of extraocular UM extension following different bioptic techniques including fine needle aspiration biopsies [911] (Table 1). The risk for tumor cell seeding, however, cannot be fully excluded and should therefore be considered when opting for biopsy and while performing surgery. Additionally, it should be mentioned when obtain- arrow) and extrascleral (arrow) tumor portions. Original magnification, $\times 2.5$. HE staining. d Serial sections demonstrated an area of tumor-free choroid with some fibrotic alteration between the radiation scar in the inferotemporal quadrant and the newfound melanoma at the pars plana, thereby failing to establish a continuity between the original and the recurrent tumor. Original magnification, $\times 10$. HE staining. * Bruch's membrane. Co, cornea; Sc, sclera; Ch, choroid.

ing informed consent from patients. That is because both local recurrence and extraocular extension, which may result from iatrogenic tumor cell seeding, decrease the patients' chance of a tumor-free survival [12, 13]. Fortunately in our case, and despite recurrence and monosomy 3 , neither hepatic nor other distant metastases have been detected during the 5-year follow-up period since the initial diagnosis. 
Table 1. Characteristics of 7 reported cases of presumably biopsy-related uveal melanoma cell seeding, including the present case

\begin{tabular}{|c|c|c|c|c|c|c|c|c|c|c|c|}
\hline Age & Sex & Eye & $\begin{array}{l}\text { Site of initial } \\
\text { presentation }\end{array}$ & $\begin{array}{l}\text { Initial } \\
\text { treatment }\end{array}$ & $\begin{array}{l}\text { Technique } \\
\text { of biopsy }\end{array}$ & $\begin{array}{l}\text { Time to } \\
\text { recur- } \\
\text { rence, } \\
\text { months }\end{array}$ & $\begin{array}{l}\text { Site of } \\
\text { recurrence }\end{array}$ & $\begin{array}{l}\text { Definitive } \\
\text { treatment }\end{array}$ & $\begin{array}{l}\text { Follow up } \\
\text { after definitive } \\
\text { treatment, } \\
\text { months }\end{array}$ & $\begin{array}{l}\text { Meta- } \\
\text { static } \\
\text { disease }\end{array}$ & Ref. \\
\hline 61 & M & OS & $\begin{array}{l}\text { Inferotemporal, } \\
\text { postequatorial }\end{array}$ & $\begin{array}{l}\text { Plaque brachy- } \\
\text { therapy (I-125) }\end{array}$ & FNAB (25G) & 8 & $\begin{array}{l}\text { Episclera } \\
\text { (superonasal) }\end{array}$ & Local excision & Unknown & No & $\begin{array}{l}\text { Caminal } \\
\text { et al. [9] }\end{array}$ \\
\hline 74 & $\mathrm{M}$ & OS & $\begin{array}{l}\text { Temporal, } \\
\text { postequatorial }\end{array}$ & $\begin{array}{l}\text { Proton beam } \\
\text { teletherapy }\end{array}$ & $\begin{array}{l}\text { PPV } \\
(25 G) \\
\end{array}$ & 14 & $\begin{array}{l}\text { Episclera } \\
\text { (nasal) }\end{array}$ & $\begin{array}{l}\text { Local excision }+ \\
\text { cryotherapy }\end{array}$ & 3 & No & $\begin{array}{l}\text { Raja } \\
\text { et al. [10] }\end{array}$ \\
\hline 80 & $\mathrm{~F}$ & $\begin{array}{l}\text { Un- } \\
\text { known }\end{array}$ & $\begin{array}{l}\text { Anterior }+ \\
\text { posterior } \\
\text { vitreous cavity }\end{array}$ & None & FNAB & 5 & Episclera & $\begin{array}{l}\text { None, delayed } \\
\text { enucleation } \\
\text { ( } 45 \text { months after } \\
\text { detection of } \\
\text { recurrence) }\end{array}$ & 46 & Yes $^{\dagger}$ & $\begin{array}{l}\text { Schefler } \\
\text { et al. [11] }\end{array}$ \\
\hline 47 & $\mathrm{~F}$ & OD & Unknown & $\begin{array}{l}\text { Plaque } \\
\text { brachytherapy } \\
\text { (I-125) }\end{array}$ & $\begin{array}{l}\text { FNAB, } \\
\text { PPV }(2 \times)\end{array}$ & 21 & $\begin{array}{l}\text { Conjunctival } \\
\text { fornix (inferior), } \\
\text { orbit }\end{array}$ & $\begin{array}{l}\text { Systemic } \\
\text { chemotherapy } \\
\text { (experimental } \\
\text { protocol) }\end{array}$ & Unknown & Yes & $\begin{array}{l}\text { Schefler } \\
\text { et al. [11] }\end{array}$ \\
\hline 10 & $\mathrm{~F}$ & OS & Unknown & $\begin{array}{l}\text { Plaque } \\
\text { brachytherapy }\end{array}$ & $\begin{array}{l}\text { Biopsy }(2 \times \text {, } \\
\text { unknown } \\
\text { technique })\end{array}$ & 108 & $\begin{array}{l}\text { Upper eyelid, } \\
\text { orbit }\end{array}$ & Exenteration & 84 & No & $\begin{array}{l}\text { Schefler } \\
\text { et al. [11] }\end{array}$ \\
\hline 63 & $\mathrm{M}$ & OS & Inferonasal & Enucleation & $\begin{array}{l}\text { FNAB, } \\
\text { PPV, } \\
\text { sclerotomy }\end{array}$ & 36 & $\begin{array}{l}\text { Conjunctiva, } \\
\text { orbit }\end{array}$ & $\begin{array}{l}\text { Resection, adjuvant } \\
\text { radiation, systemic } \\
\text { immune therapy }\end{array}$ & 6 & Yes & $\begin{array}{l}\text { Schefler } \\
\text { et al. [11] }\end{array}$ \\
\hline 66 & $\mathrm{M}$ & OD & $\begin{array}{l}\text { Inferotemporal, } \\
\text { postequatorial }\end{array}$ & $\begin{array}{l}\text { Plaque } \\
\text { brachytherapy } \\
(\mathrm{Ru}-106)\end{array}$ & $\begin{array}{l}\text { PPV } \\
(25 G)\end{array}$ & 24 & $\begin{array}{l}\text { Episclera }+ \\
\text { pars plana }(\mathrm{su} \\
\text { perotemporal) }\end{array}$ & Enucleation & 12 & No & $\begin{array}{l}\text { Present } \\
\text { case }\end{array}$ \\
\hline
\end{tabular}

$\mathrm{OD}$, right eye; OS, left eye; FNAB, fine needle aspiration biopsy; PPV, pars plana vitrectomy. ${ }^{\dagger}$ Uveal melanoma-related death.

\section{Acknowledgements}

Supported by German Research Foundation (FOR 2240 "(Lymph)Angiogenesis and Cellular Immunity in Inflammatory Diseases of the Eye" to L.M.H.; HE 6743/2-1 and HE 6743/3-1 to L.M.H.), German Cancer Aid (to L.M.H.), and "Gerok" Grant from the University of Cologne (to K.R.K. and L.M.H.).

\section{Statement of Ethics}

For this type of study, formal consent is not required. This article does not contain any studies with animals performed by any of the authors. Informed consent was obtained from all individual participants included in the study.

\section{Disclosure Statement}

The authors declare that they have no conflict of interest.

\section{References}

1 Jensen OA, Andersen SR: Late complications of biopsy in intraocular tumors. Acta Ophthalmol (Copenh) 1959;37:568-575.

2 Abi-Ayad N, Grange JD, Salle M, Kodjikian L: Transretinal uveal melanoma biopsy with 25-gauge vitrectomy system. Acta Ophthalmol 2013;91:279-281.

3 Singh AD, Medina CA, Singh N, Aronow ME, Biscotti CV, Triozzi PL: Fine-needle aspiration biopsy of uveal melanoma: outcomes and complications. Br J Ophthalmol 2016;100: 456-462.

4 Dithmar S, Völcker HE, Grossniklaus HE: Multifocal intraocular malignant melanoma: report of two cases and review of the literature. Ophthalmology 1999;106:1345-1348.

5 Akgul H, Otterbach F, Bornfeld N, Jurklies B: Intraocular biopsy using special forceps: a new instrument and refined surgical technique. Br J Ophthalmol 2011;95:79-82.
6 Metz CH, Lohmann D, Zeschnigk M, Bornfeld N: Uveal melanoma: current insights into clinical relevance of genetic testing. Klin Monbl Augenheilkd 2013;230:686-691.

7 Van Raamsdonk CD, Bezrookove V, Green G, Bauer J, Gaugler L, O'Brien JM, Simpson EM, Barsh GS, Bastian BC: Frequent somatic mutations of GNAQ in uveal melanoma and blue naevi. Nature 2009;457:599-602.

8 Ambrosini G, Sawle AD, Musi E, Schwartz GK: BRD4-targeted therapy induces Myc-independent cytotoxicity in Gnaq/11-mutatant uveal melanoma cells. Oncotarget 2015;6: 33397-33409.

9 Caminal JM, Sanz S, Carreras M, Català I, Arruga J, Roca G: Epibulbar seeding at the site of a transvitreal fine-needle aspiration biopsy. Arch Ophthalmol 2006;124:587-589.
10 Raja V, Russo A, Coupland S, Groenewald C, Damato B: Extraocular seeding of choroidal melanoma after a transretinal biopsy with a 25-gauge vitrector. Retin Cases Brief Rep 2011;5:194-196.

11 Schefler AC, Gologorsky D, Marr BP, Shields CL, Zeolite I, Abramson DH: Extraocular extension of uveal melanoma after fine-needle aspiration, vitrectomy, and open biopsy. JAMA Ophthalmol 2013;131:1220-1224.

12 Heindl LM, Hofmann TN, Adler W, Knorr HL, Holbach LM, Naumann GO, Kruse FE, Cursiefen C: Intraocular tumor-associated lymphangiogenesis a novel prognostic factor for ciliary body melanomas with extraocular extension. Ophthalmology 2010;117:334-342.

13 Ophthalmic Oncology Task Force: Local recurrence significantly increases the risk of metastatic uveal melanoma. Ophthalmology 2016;123:86-91. 